\title{
Bibliographical Services in the Arab Countries
}

\section{INTRODUCTION}

$\mathrm{T}$ HE PURPOSE OF THIS ARTICLE is to assist acquisition and reference librarians and bibliographers in identifying specific titles and book production in the Arab world. With the use of basic national and subject bibliographies, the librarian will be able to trace titles requested by the historian, the social or political scientist, the geographer, the general reader, or any student of Middle Eastern affairs. The aim of this work is to indicate the available bibliographies and to discuss their importance, use, scope, and arrangement. It also intends to point out the feasibility of establishing an Arab bibliographical center which will be responsible for compiling and publishing a national bibliography for all the Arab states and union lists of serial holdings in all the Arab libraries. These and other bibliographical activities would certainly be considered a step forward not only for the Arab nations, but also for international bibliographic cooperation.

The first comprehensive Arabic national bibliography was compiled by Ibn al-Nadim. ${ }^{1} \mathrm{He}$ assembled the Arabic literature of the first four centuries after Hijra by a bio-bibliographical method different from that used in other contemporary sources. In his bibliography Miftah al-Sa"adah wa Misbah alSivadah fi Mafatih al-"Ulum, Tashkubra

Dr. Aman is a Lecturer at Pratt Institute's Graduate School of Library and Information Science, Brooklyn, N.Y.
Zada (d. 1528) covers the Arabic literature available during the thirteenth and fourteenth centuries. One century after Zada, Hajji Khalifah (d. 1657) compiled his bibliography Kashf al-Ohunun "An Asami al-kutub wal Funun.2 His bibliography was intended as an inventory of titles of all books available in Arabic, Turkish, and Persian languages. ${ }^{3}$

The dawn of the twentieth century marked a new era in the history of Arabic culture and bibliography. After five centuries of mental lethargy, beginning with the eruption of the Mongols into the Muslim world in the thirteenth century, a renewed zeal for learning dispelled the gloom which so long overshadowed the Arabic speaking countries. For centuries, many factors had been at work to bring about a beneficial change in the Arab bibliographical activities. The West began to take varied interest in the dormant East by collecting, organizing, and studying its longforgotten literatures.

This renaissance added new elements to Arab librarianship and bibliographical control. Legal deposit laws were introduced in the Arab countries, book catalogs and national and subject bibliographies began to be published by research and academic libraries.

In the first half of the twentieth century the Arab world was lagging behind in respect to proper bibliographical control of materials and adequate bibliographical services in all its aspects. At the time before independence there were a few bibliographies which were compiled and published by Orientalists, 
Egyptologists, and Middle East Specialists. The subject limitation of these bibliographies can be defined as historical, religious, and literary.

The most noteworthy example of such contributions is Brockelman's historical bibliography of Arabic literature from the earliest times to the twentieth century. ${ }^{4}$ This bibliography is still a valuable source of both available and unavailable Arabic manuscripts and early books in different subjects. Zidan has also listed Arabic titles by subjects using other Arabic bibliographies as sources for his compilation. ${ }^{5}$

Although copyright deposit systems were nonexistent in any of the Arab countries before the nineteenth century, Egypt had a Press and Registration of Books Act as early as 1799. However, it was not for depository reasons. The law did not mention any depository libraries and all publications were never made available at a single center. In 1881 a "Publication Law" was issued as the first complete or integrated legislation requiring clear identification of publications either written, printed, or published in modern Egypt.

A common feature of the earliest Arab bibliographies is that they are the works of individuals, with little or no outside financial or moral support. It is due entirely to the determination and dedication of Arab scholars like Father Qanawati, Joseph Dagher, Sirkis "Awwad and others that the literature of the Arab world has been documented. ${ }^{6}$ Arab libraries have only recently become aware of the part that they should play in the production of bibliographic reference tools. In almost all of the Arab states (with the exception of Saudi Arabia), national libraries are now entitled to receive locally published material under the terms of their legal deposit act.

National Bibliographies

The individual Arab national libraries have advanced rapidly in carrying their responsibilities as their nation's bibliographical centers and depository libraries. Almost all the Arab national libraries, where they exist, issue national bibliographies that vary in coverage and frequency. Lack of effective legal deposit laws, and lack of effective or automated methods in compiling Arabic bibliographies have contributed to the inadequacy in coverage, irregularity in publication, and to inefficiency in issuing their national bibliographies.

In Algeria the National Library issues its Bibliographie de l'Algerie. The first issue appeared October 1, 1963, and listed more than 100 periodical titles in either Arabic or French, which had been deposited in the National Library from July 1962 through September 1963 in compliance with the legal deposit act. The second issue of the bibliography was published in 1964 and listed books and theses received through legal deposit from July 1962 through June 1964 . The arrangement of the bibliography is by the Universal Decimal Classification (UDC) with author or corporate, and title indexes. Retrospective bibliographies for Algeria are represented by works of Fiori and Sir Robert Playfair. ${ }^{7}$

In Iraq the Central Library of the University of Baghdad has been publishing its accessions list which covers materials received by legal deposit. Its Fihris Mwdu'i, Majami" al-Kutub al"Arabiyyah al-Mawjudah fil-Maktaba alMarkaziyyah is a subject list of Arabic holdings of the Central Library and was first published in three volumes in 1966 covering the years 1959-1965. A retrospective bibliography of Iraq was compiled by S. C. Dodd and was published by the American University of Beirut. $^{8}$

In Jordan the University of Jordan Library, which acts also as a national library, receives one or two copies of any publication (books and government publications) printed or published by 
Jordanians. However, there is no printed national bibliography available for Jordan. One has to depend on the individual subject bibliographies which are issued by the Libraries Section at the Ministry of Education and on the bibliographical lists published by the University of Jordan Library. Some select Jordanian publications are listed in the Arab publishers' record "al-Maktaba" which is published in Baghdad and lists trade books from Iraq, Jordan, Lebanon, and Syria. Dodd's retrospective bibliography covers Trans-Jordan and Palestine as well.

Kuwait has no national bibliography, but annual subject bibliographies on the history and geography of the state are published in the general periodical Kuwait Today. A source of bibliographical importance is also the book list published in Al-"Arabi, which is a monthly magazine published in the State of Kuwait.

In Lebanon there exists a law for legal deposit. According to a 1952 law four copies of each new publication are sent to the Ministry of Information, of which one is for the Ministry of Information, one for the Ministry of Education, and two for the National Library. The National Library is solely responsible for editing and publishing the Lebanese National Bibliography which first appeared in 1965 covering the year 1964. The bibliography includes books written or translated by Lebanese and books published in Lebanon regardless of language or nationality of the author. The Lebanese National Bibliography is arranged in approximate Dewey Decimal Classification but without decimal numbers.

In Libya the government libraries in Tripoli and Benghazi act as a national library and acquire copies of printed material (other than periodicals and semiperiodicals) in compliance with Article 47 of Act no. 11 of 1959 . However, neither of these two libraries is- sues a national bibliography or a list of deposited material.

The best available retrospective bibliographies for Libya are Hill's work and the Archivio Bibliografico Coloniale, which was published by the Societa Italiana per lo Studio della Libia e delle altre Colonie. ${ }^{9}$

The Bibliothèque Generale et Archives du Maroc, in spite of technical and administrative difficulties, has been able to carry on its responsibility as the nation's bibliographic center. Paramount on the list of its bibliographical activities is the continued publication of the Bibliographie nationale marocaine which is issued monthly and is arranged by UDC. Retrospective national bibliographies are represented by the series Liste des Publications d'esposèes à la bibliothèque générale et archives au titre $d u$ depôt legale au cours de l'annèe. . . . The bibliography is published in two parts which vary in their coverage. The 1948-59 cumulation was divided into (a) official publications, and (b) other publications. The two parts for 1960-66 include: (a) works in Arabic, French, and foreign languages, and (b) Dewey Decimal Classification.

Other retrospective bibliographies have also been issued by the library. The Informations bibliographiques marocaines 1931-62 describes books and magazine articles concerning Morocco. The arrangement is classified in alphabetical order under five main headings: administrative, political, economic and social questions, agriculture, pure sciences, human sciences. The Catalogue des manuscripts arabes des Rabat was compiled in the Bibliothèque Generale and was published in two volumes. Other retrospective bibliographies were published by different authors under the title Bibliographie marocaine covering the years $1923-35$ and 1957.

In Saudi Arabia, although the National Library in Riyadh obtains works by Saudi Arabian authors who send 
sample copies for purchase consideration, there has been no attempt to publish a national bibliography. No effort has been made to issue a copyright legal deposit act.

In Syria the Bibliothèque Nationale Zahiriyeh receives two copies of each new publication in compliance with the legal deposit act. Some titles are also received and listed by the University of Damascus which issues its monthly acquisition bulletin, Bulletin mensuel des publications reçues.

The official national bibliography of the United Arab Republic was formally initiated in 1955 as the result of the recommendations of the Egyptian National Bibliography Committee. The Committee aims at "complete registration of the Arabic book, since the invention of printing to the present." The Legal Deposit Acts of 1954 and 1968 enforced the requirement for each printer or publisher to furnish ten copies upon publication. The National Library is considered the obvious body to undertake the task of compiling the Egyptian National bibliography, since it receives these deposit copies for almost everything published in the country, and as far as the retrospective bibliography is concerned, it has copies of most of the material printed in the country from the earliest times.

The Egyptian Publications Bulletin, known in Arabic as "al-Nashrah al-misriyyah lil-matbu"at, was first issued three times a year 1955-1959. The first cumulation for the issues of the Bulletin for the five years 1956-1961 was published in 1962. Since 1961 the Bulletin has been published annually with biennial cumulation. The annual issues are divided into a classified list of printed works, excluding textbooks and children's books, which are listed in the second part. A separate volume is devoted to materials printed locally in foreign languages. The modified Dewey Decimal Classification is used for sys- tematic arrangement of the titles without the classification number. Under each subject the main entry is by title of the book printed in heavy type on a separate line. The second print line gives the author's full name, place of publication, publisher's name, date of publication, number of pages, size, price, series (if any), and call number. Each page is divided into two columns, and the entries are given a serial number. Each volume has author, title, and subject indexes.

Fast bibliographical service covering trade books is offered in the quarterly issues of the Arab periodical "Alam alMaktabat (Library World). ${ }^{10}$ The periodical includes, among other library news and articles, classified listings of new publications, reviews, and publisher's announcements both from the U.A.R. and other Arab publishers. Another bibliographical coverage mostly by subject is included in the quarterly, Mijallat al-Kitab al"Arabi, which is published by al-Mu'assasah al-Misriyyah lilMatbu"at.

Egyptian retrospective bibliographies are too numerous to list here. However, brief mention should be made of the Cultural Record (al-Sijil al-thaqafi) for 1947-1948; the annual bulletin of additions to the National Library, and its printed catalogs covering the period from 1892 to 1949 . Recently a study and bibliography of Arabic books printed in Egypt during 1926-1940 was compiled as part of a master's study at Cairo University. ${ }^{11}$

In the current national bibliographies of Arab states one will find a general characteristic of compilation common to most of them. These bibliographies are divided systematically according to subject with the necessary alphabetical indexes-usually author, title, and verbal subjects. The main entries under subjects are usually arranged by titles. The frequency of some of these bibliographies vary. Some are issued an- 
nually (U.A.R.) while others are issued quarterly, and virtually none on a monthly basis. In most cases, however, the bibliography is issued about a year later than its coverage; for example the 1967 issue covers material deposited during 1966.

\section{Government Documents}

The importance of obtaining Arabic government documents and the information included in them need not be argued. They contain invaluable source material, and their importance to the general public, scholars, businessmen, and scientists cannot be fully estimated. However, Arab government publications do not always find their way into the right hands. Unfortunately, old documents are often destroyed before thought is given to keeping these materials in the proper manner by a responsible agency. What comes from government departments are books and monographic material, not the important documents and limited distributed publications. This situation reflects upon Arab librarianship in the sense that there is as yet no investigation as to the problems of cataloging, distributing, and using Arabic government publications.

The situation is severely aggravated by the lack of obligatory laws which make government documents subject to legal deposit in the national library, and perhaps also in city libraries. Very few government publications find their way to the depository libraries, and therefore many documents are missing from Arab national bibliographies. Jordan can be considered the only exception since the University Library receives government documents as depository items. Unfortunately there is no available bibliography of material deposited in the Library.

The Moroccan national bibliography lists official publications in section "A" of its Bibliographie Nationale Moracaine.
In Syria the government documents of a few departments are listed in bibliographies issued by the sections of libraries in these departments. The Educational Archives Service of the Ministry of Education issues its Bulletin d'Archives Pédagogiques listing official publications of the Ministry. The Direction des Bibliothèques in the Ministry of Culture, Tourism and National Guidance publishes its Bulletin Trimestriel des Publications du Ministère.

A retrospective bibliography of $\mathrm{Tu}$ nisian official periodical publications, Recapitulations des Périodique Officiels Parus en Tunisie de 1881 à 1955, was published by the Tunisian National Library in 1956.

Official publications of the U.A.R. Ministry of Education are listed by the Documentation Center in the Ministry. The first cumulative list of these publications was published by the Center in 1961 covering the periods $1950-1960 .{ }^{12}$ Another important subject bibliography was first issued by the Center in 1961 containing all texts of laws, decrees, and public orders issued by the Ministry during $1959 .^{13}$

The new Arab Political Encyclopedia, published by the Egyptian Documentation Research Center includes legislation, texts of constitution, acts, President's speeches, and other related official documents. Other sources, such as al-Nashrah al-Tashri"iyyah, Mawsu"at al-"Amal Wal-Ta'minat, and al-Waga'i" al-Misriyyah, should be consulted as sources of legal publications and official acts and decrees.

The only available example of a separate retrospective listing of Egyptian official publications is the one which was issued in 1959 by the U.A.R. National Library covering select Egyptian official publications issued in the U.A.R. during the years $1952-58$ and available in the National Library. The Bibliography lists Arabic, English, and French documents. ${ }^{14}$ 


\section{Serial Publications}

For up-to-date details regarding periodicals published in the Arab countries research workers and scholars would do well to turn to the classified Directory of Current Periodicals Published in the Arab World. The Directory was published in 1965 in cooperation with UNESCO which sponsored this and other bibliographical projects in the Arab states; the Directory does not, however, serve as a union list of the locations of the listed periodicals. The bibliographic description includes titles, publisher, frequency, price, address, year of first publication, and termination (if the title has ceased publication).

The National Library of Algeria has issued in three volumes its Liste des Périodiques français et étrangers en cours conserves dans les bibliothèques et centres de documentation des départements.

In Morocco the new Moroccan periodicals are listed in the retrospective volumes of the Bibliographie Nationale Marocaine. In 1964 the French and foreign language section of the Periodicals Service of the Bibliothèque Générale et Archives du Maroc issued a list of current periodicals published in Morocco.

The leading example of a comprehensive listing of serial holdings of one Arab library is that of the U.A.R. National Library's two-volume List of $\mathrm{Pe}$ riodical Holdings. ${ }^{15}$ The bibliographical information includes title, year first published, frequency, price, publisher, address, name, and capital of the Arab country where the publication originated, and the call number in the National Library. Volume 1 contains a list of 2,144 periodicals with titles arranged in alphabetical order. Volume 2 is an index by place and frequency of publication. It also includes chronological arrangement for entries, and an index by subjects.
A tool to be used in conjunction with the above two lists of Arabic serials is the Analytical Index to Arabic Newspapers and Periodicals. ${ }^{16}$ This venture was started under the editorship of Mahmud al-Shiniti in 1962. The Index does not cover every journal or periodical in the Arab world. Only the most significant or generally useful are included. Scholarly journals and in particular those in scientific and technological fields, are not covered in the Index, and the more general and popular magazines are most fully indexed.

Other subject indexes to articles in a given subject area have been published by different Egyptian organizations. The National Institute of Management has issued guides to periodical literature published in Arabic dealing with social and economic planning. ${ }^{17}$

A more recent attempt to index scientific literature during the year 1968 was published by Abul Futuh "Udah, in the Egyptian quarterly, Mijallat alkitab al-“Arabi.

\section{THESES}

Arab students and scholars are unfortunate in not having at their disposal a comprehensive bibliography of master's or doctoral theses which have been presented at Arab universities since their establishment. In 1963 the first attempt to compile a list of theses submitted to Cairo University was completed and published in the Arab Library Journal "al-Maktaba al-"Arabiyyah."18 The list was compiled by Egyptian students in the master's program in the Department of Archives and Librarianship at Cairo University. It is a subject list with author and title index. The subject matter of each thesis is determined by the title. The entry includes the author's name, the title of the thesis, the department to which it was presented, and the year it was submitted.

The Universities of Alexandria and Ein Shams also issue lists of theses sub- 
mitted to their departments. ${ }^{19}$ The National Research Center in Cairo has been publishing annual listings of its theses in science. The titles in the list are translated into English. ${ }^{20}$ Al-Azhar University has also published its list of academic dissertations submitted to the faculties of Shari"ah Usul al-Din and Arabic Language..$^{21}$ Although Egyptian students abroad are submitting more theses to academic institutions than the Egyptian students at home, there has been no attempt to compile a list of theses submitted by those Egyptian students who are completing their graduate studies in foreign countries. The great majority of these students are on government scholarships and are required by law to deposit three copies of the Ph.D. thesis and two copies of the master's thesis with the Cultural and Educational Bureau of the U.A.R. embassy in the country where they submitted their theses. The present writer has suggested that the U.A.R. Cultural and Educational Bureau in Washington should take the lead in compiling lists of the theses it obtains from Egyptian students, and serve as a leading example to what the other U.A.R. educational bureaus overseas should follow. ${ }^{22}$

The American University Library in Beirut makes regular mention in its monthly acquisition bulletin of theses and dissertations presented by students of the various faculties for final examinations.

\section{Subject Bibliography}

The number of subject bibliographies has been increasing copiously during recent years. Many subjects have been covered by the national libraries. The Bibliographical Series of the Egyptian National Library is an example of the type of work being carried out. The Libraries Section in the Jordanian Ministry of Education prepares occasional bibliographies on different subjects of interest to teachers, schools, and teacher-training colleges. The bibliographies deal with children's literature, textbooks, etc. The Library of the University of Jordan issues regularly a bibliography of books on psychology in both Arabic and English. The only tool which listed Arabic bibliographies by country and subject is the Bibliography of Arabic Bibliographies which was compiled by by Ahman "abdel Halim as part of his studies at the London School of Librarianship in 1961. This bibliography was never published and no attempt was made to supplement such an important work.

A brief mention could be made of the Egyptian National Library's subject bibliographies on the Arab world, Egypt, Arabic incunabula, Arabic manuscripts, Persian manuscripts, and other important subject bibliographies.

The Middle East Science Cooperation Office of UNESCO has issued the Middle East Social Science Bibliography which is a classified list of books and articles on the social sciences published in the Arab countries in 19551960.

\section{ACCESSION LISTS}

Accession lists and library catalogs are issued by different Arab libraries. These lists of additions are also valuable sources for finding new publications, particularly those published by other Arab countries. The most active libraries are those of the Universities of Cairo, Iraq, Lebanon, and Syria. ${ }^{23}$ Other government and research libraries also publish their own accession lists.

\section{Current State of and Proposed Solutions for Arab Biblio- GRAPHICAL CONTROL}

It is to be regretted that the individual Arab states that publish national bibliographies are not publishing them soon enough after the time of publication of the books included. All too fre- 
quently the printed bibliography is issued so much later that the bibliographic information itself becomes somewhat of an academic matter. There is a need for a comprehensive periodical and general cataloging and indexing service for Arabic government documents. Any of the available Arabic lists of serials need to be brought up to date by issuing the necessary supplements within short periods of time to achieve continuity of coverage. A union list of Arabic periodicals indicating exact holdings for each major library in the region would serve as a valuable research tool.

There is a need also for an Arabic periodical and newspaper directory, to be issued annually and to include all continuations, whatever their frequency and publishers, whether government, association, business corporation, or any other. Complete information should include history, indexes (if any), and special features. The Arab states need a current listing of material about themselves. There is need for a single, comprehensive, frequent publication which would index by subject, and at least annotate, or preferably abstract, all material relating to the Arab world, wherever published, in whatever form.

Of equal importance to compiling a national bibliography for the Arab world is the identification of the purposes and objectives of a national bibliography which seems now to be lacking in the Arab library community. An Arab national bibliography should serve at least two definite purposes. The first would be commercial, in the sense of serving the needs of the book trade, by issuing lists of all new publications. The secondary function is of a more lasting nature, supplying a complete and permanent record of all printed matter for the research worker.

The foundation of the scheme for bibliographic control in the Arab states must be a comprehensive list, issued frequently and cumulated regularly, of everything produced in the Arab nation. National production includes trade publications, both books and pamphlets; privately printed materials; government publications, including separate serials, printed and otherwise processed; university theses, completed and in progress; periodicals and newspapers.

This implies the establishment of an Arab central agency whose immediate duty would be to devise means of bringing material promptly to the Arab bibliographic centers for listing. The cooperation of publishers would be enlisted, first on the basis of goodwill, and second on that of self-interest, since a listing will constitute a free advertisement. In addition copyright laws must be revised and enforced in such a way as to ensure the deposit of copies in the Arab national libraries.

As far as the Arab national coverage is concerned, there is a real need for a union catalog of works published in or on the Arab world and forming part of the collection of libraries of the Arab states. A union catalog of Arabic documentation available in libraries of all types in the Arab world will facilitate an Arab national coverage. Also needed is a list of official publications printed in the Arab countries or relating to them. A national union catalog of periodicals and newspapers published in or on the Arab countries should be published in a loose-leaf form which is easy to update. A regular listing of theses submitted to Arab universities or by Arab students abroad is needed in order to promote research activity in the Arab world. To complete the bibliographical control in the Arab nation, a bibliography of sound recordings produced in the Arab world or relating to it can either be published separately or appended to the proposed Arab national bibliography. The same might also include films, filmstrips, and slides produced in or related to the Arab world. 
These activities can be organized through the league of Arab states with the cooperation of UNESCO and through establishing a federation of Arab library associations. The collaboration of all the libraries is essential if the various needs of bibliographical control in the Arab world are to be achieved.

Obviously any such cooperative effort implies agreement on bibliographical standards. The Arab League and UNESCO could provide the facilities for national representatives to work together to produce an Arab code. Each cooperating state should contribute financially to the compilation and assume responsibility for analyzing its own national production and forward the analyses to the Arab national compilers.

The main purpose of publishing a comprehensive current regional bibliography for the Arab world is to develop an effective means of achieving wider bibliographic coverage on a more current and broader basis. The emphasis at the present time should be on currently published materials of the Arab countries. This in itself would also assure prompt acquisition by interested librarians and individuals within the Arab world and abroad.

The first attempts at regional coverage of Arab library resources and activities are to be considered steps toward meeting the appeal of UNESCO for an exhaustive national list of current publications and for a complete record of past publications. These attempts have resulted in publishing $A$ Directory of Current Periodicals published in the Arab world compiled by M. El-Mahdi in 1965. Another one, entitled Directory of Archives, Libraries, Documentation Centers and Bibliographical Institutions in the Arabic States, was compiled by Ahmad Badr and published by the UNESCO office in Cairo in 1965.

Another example of the present limited regional bibliographical coverage is the listing of books published in Iraq, Jordan, Lebanon, and Syria in the semiannual periodical Al-Maktaba (The Library). This periodical serves as a select publishers' record for these four Arab countries. The entries are arranged under broad subjects with annotations in Arabic and English translations. The recent publication of the Arab World Index covering 1960-64, and al-Dalil alBibliojrafi lil-Qiyam al-Thaqafiyysh al"Arabiyyah and the American University of Beirut's list Selected and Annotated Bibliography of Economic Literature on the Arabic Speaking Countries of the Middle East are a few examples of the increasing Arab bibliographical activities to meet the needs of scholars for overall national bibliographical control.

An Arab Bibliographical Center such as is here proposed would meet most of the urgent bibliographic needs of scholars, research libraries, government authorities, and others who are concerned with the Arab countries. Before such a Center could be established, a number of organizational problems would have to be carefully considered and worked out, such as its location, its relation with other institutions, its budget and method of financing.

In choosing a location for the Center it would seem evident that immediate proximity to a major national library of the Arab states would be a first priority. Representatives of the Arab Bibliographical Center should be chosen from the most active libraries in the states whether they be national, university, or central public libraries. Libraries with legal deposit privileges should be given top priority.

The location of such a Center can only be determined by the mutual agreement of Arab national librarians. This project would also require agreement among publishers as to how to provide the Arab Bibliographic Center with copies of new publications. 
The Cultural Committee of theany language as long as it deals with League of Arab States has taken the initiative to propose what was called "Markaz Tasjil al-Matbu“at al-"Arabiyyah" (Center for Registration of Arabic books). The recommendations which were adopted in the Committee's sixteenth annual session, February 16-23, 1963, stated:

... That the Cultural Department of the League of Arab States prepare periodical lists of all works issued by Publishing firms in the various Arab States. These lists would be circulated, as they appeared, to the Arab governments, thus helping to strengthen publishing in the Arab countries.

That the Arabic Manuscripts Institute of the League of Arab States in conjunction with the Documentation and Publication Centre produce a scheme for a periodical bulletin listing manuscripts in the Arab countries, whose recension and publication had either actually been effected or was projected.

That two copies of any work published in an Arab country, whether an original work, a translation or work edited in that country, be lodged through the Government concerned in the library of the Secretariat-General of the League, to provide a central depository of Arab States. ${ }^{24}$

Such a bibliographic center would also publish a comprehensive annotated bibliography. Its ultimate goal would be to include everything that is published anywhere in the world and in

\section{the Arab world.}

The other important activity of the Center would be the establishment and maintenance of an Arab national union catalog of all materials available in Arabic. The Bibliographic Center could assist Arab and foreign librarians in many essential ways. For certain areas of knowledge which are especially germane to the area, the Center would also have to function as an international center for Egyptology, Islam, Arab and Middle Eastern sources, by collecting material and publishing abstracts for all related literatures that it would receive.

Publishing of printed cards and distributing them to participating libraries of the Arab states would avoid the national waste of hundreds of classifiers and catalogers processing the same title in hundreds of Arab libraries. The Arab national economy will also be secured through a higher order of conformity to standards which will be made possible through a central processing center. Such a mode of national economy is already accomplished in the United States and the Soviet Union, South Africa, and other countries.

The Center would be the proper agency to take charge of this Arab bibliographic coordination through its cooperative classification and cataloging. Gradually the Center would make sets of catalog cards available to libraries in the Arab states and abroad.

\section{REFERENCES}

1. Ibn al-Nadim, Kitab al fihrist; mit anmerkungen hrsq. von Gustav Flugel (Leipzig: F.S.W. Vogel, 1871-72).

2. Hadjdji Khalifah, Kashf al-dhunun "an asami al-kutub wal funun. 2 vols. (Cairo: Bulaq Press, 18-).

3. For more information on early Arabic bibliographies see the second chapter in the writer's theses: Analysis of Terminology, Form and Structure of Subject Headings in Arabic Literature. . . . (Ph.D. dissertation, University of Pittsburgh, Graduate School of Library and Information Sciences, 1968).

4. Karl Brockelmann, Geschichte der arabischen literature ( $2 \mathrm{~d}$ ed.; Leiden, 1937-42), 2 vols. and 3 suppls.

5. Jurji Zidan, Tarikh adab al-lugha al“arabiyya (Cairo: Dar al-Hilal, 1957).

6. Sirkis "Awwad, comp., Mu "jam almatbu "at al. "arabiyyah (Dictionary of Arabic books) (Cairo: Matba "at Sarkis, 1928-31).

7. Herman Fiori,... Bibliographie des ouvrages imprimes à Alger de 1830 à 1850 . . . preface de G. Esquer . . . 
(Blica, Alger: l'auteur, 1938); Sir Robert Lambert Playfair, A bibliography of Algeria, from the expedition of Charles V. in 1541 to 1887 (Royal Geographical Soc. Suppl. papers. London, 1889). Also by the same author: Supplement to the bibliography of Algeria from the earliest times to 1895 . Supplement. From the earliest times, to 1895 , published in London, 1898. (Part 2 of his bibliography of the Barbary States.)

8. Stuart Carter Dodd, A Post-war Bibliography of the Near Eastern Mandates: A preliminary survey of publications on the social sciences dealing with Iraq, Palestine, and Trans-Jordan, and the Syrian States, from Nov. 1, 1918 to Dec. 31, 1929, arranged in an alphabetical list by authors, with a limited index by subject matter. (Beirut: American Press, 1933-36). (Social Science Publication Series 1-4, 6-8).

9. Roy Wells Hill, A Bibliography of Libya (Durham University, Durham Colleges. Geography, Dept. of Research Papers, series no. 1. Durham, 1959.) Archivio bibliografico coloniale (Libya) Anno 1-42. (Maggio, 1914 July 1921, Firenze, 1915-21).

10. "Alam al-maktabat, v.1- , no. 11957- (bimonthly).

11. "Aydah Ibrahim Nusayr. al-Kutub al"Arabiyyah allati nushirat fil-Jumhuriyyah al-"Arabyyah bayn "Amy 19261940; dirasah wa bibliujrafia. (Cairo: University of Cairo, 1966). (Master's Thesis, Department of Archives and Librarianship, Cairo University, 1966.)

12. U.A.R. Wizarat al-tarbiyah wal-ta"lim, al-dalil al-bibliiirafi li-matbu" at wizarat al-tarbiyah wal-ta "lim 19501960. (Cairo, 1961).

13. U.A.R. Wizarat al-tarbiyah wal-ta"lim. Markaz al-wath'iq wal-buhuth al-tarbawiyyah. al-Fihris al-abjadi al-mawdu" $i$ lil-qawa" in wal-qaarat al-jumhuriyyah wal-wizariyyah wal-manshurat al-"Ammah wal-kutub al-dawriyyah al-muta" alliqah bi-a"mal wizarat al-tarbiyah wal-ta"lim ... (Cairo, 1961- ) (annual).

14. U.A.R. Dar al-kutub. Qa'imah bi ba"d al-matbu"at al-humkumiyyah allati sadarat fil-iqlim al-misri fi "ahd al- thawrah fil-fatrah $\min$ 1952-58. (Cairo: National Library Press, 1959.)

15. U.A.R. National Library and Archives. Fihris al-dawriyyat al-"Arabiyya allatitaqtaqtaniha al-dar, compiled by Mahmud Isma"il "Abdullah (Cairo, 1961, 1963) v.1, 1961; v.2, 1963.

16. al-Kashahaf al-tahlili lil-suhus wal-mijallat al-"Arabiyyah (Cairo: The Arab Library Public. 1961-date).

17. U.A.R. Ma"had al-Takhtit al-Qawmi. al-Dawriyyat al'Arabiyyah allati tasil li-markaz al-watha' iq fi majal-al-takhtit al-iqtisadi. Cairo Institute of $\mathrm{Na}-$ tional Planning. (Annual). Also by the same Institute: Ta"rif bil-matbu" at alihsa'iyyah al-dawriyyah ma"a biblioirafia mawdu"iyyah lil-maoalat al" Arabiyyaq fi-majal, al-takhtit al-ijtima" $i$ wal-iqtisadi li"am. (1964) Cairo, 1965-.

18. "Bibliujrafia al-Rasa'il al-jami”iyyah al-“Arabiyya”, Mijallat Al Maktaba al "Arabiyyah (Arab Library) 1(4), 1964, 44-128.

19. University of Alexandria, Sijill al-rasa'il. (Alexandria, 1957-date).

20. U.A.R. al-Markaz al-Qawmi lil-Buhuth. Qa'imah bil-risalat al-“ilmiyyah allati ujriyat buhuthuha bil-markaz. (Cairo: National Research Center, 1965.)

21. al-Azhar University. Qa'imat tawthig maktabi lil-rasa'il al-jami“iyyha al-mujazah bil-dirasat al-"ulia li-kulliyyat usul al-din wal-shari“ah wal-lughah al-"Arabiyyah. . . . (Cairo: the University, 1967.)

22. Mohammed M. Aman, "al-Utruhat aljam"iyyah: kayfiyyat hifdhaha wa turuq al-ta"rif biha", Zamili, 2:16-18, 1965.

23. Cairo University, Central Library, Nashrat al-magtanayat al-hadithah. Cairo, 1961- ; University of Baghdad, Central Library, Fihris mawdu" $i$ majami" al-kutub al-"arabiyyah. 1959- ; American University (Beirut) Libraries. Kutub udifat hadithan ila maktabat al-jami"ah ma"ada maktabat al"tibbiyyah; University of Damascus, Library, Bulletin mensuel des publications reçues.

24. Bibliography, Documentation, Terminology. 3(4): July 1963. 